\title{
MODEL KONVERGENSI DALAM KOMUNIKASI PEMBELAJARAN
}

\author{
Oleh: Ishak Abdulhak dan Oos M. Anwas *)
}

\section{Abstrak}

Perkembangan ilmu komunikasi mempengaruhi inovasi pendekatan pembelajaran. Model pembelajaran yang cenderung menggunakan komunikasi linier bergeser kepada komunikasi relasional. Sesuai tuntutan pembelajaran berkualitas dan efektif dikembangkan model pembelajaran dengan pendekatan komunikasi konvergen. Model ini memiliki ciri pelaksanaan belajar secara berkesinambungan dan memanfaatkan jejaring (network), serta berpijak pada kaidah kolektivitas untuk memperoleh saling pemahaman (mutual understanding). Konsekwensinya, pengajar dituntut selain memiliki kemampuan pemahaman bahan belajar, juga kemampuan menciptakan situasi pembelajaran yang kooperatif di antara peserta belajar. Implementasi model ini pada dasarnya memadukan karakteristik pendekatan pembelajaran kooperatif, percepatan pembelajaran, belajar yang menyenangkan, dan memperhatikan keunikan individual peserta belajar.

Kata Kunci: komunikasi pembelajaran, pendekatan konvergensi, pembelajaran, interaktif, kooperatif.

\section{A. PENDAHULUAN}

Secara nasional upaya pendidikan kita memiliki sejumlah indikator yang menunjukkan keberhasilan, antara lain adanya peningkatan angka partisipasi pendidikan sekolah. Tahun 1999/2000 angka

*) Prof. Dr. Ishak Abdulhak adalah Guru Besar/Dekan FIP Universitas Pendidikan Indonesia. Drs. Oos M. Anwas, M.Si adalah Peneliti Bidang Pendidikan, bekerja di Pustekkom Depdiknas. 
partisipasi murni untuk SD mencapai 25.69 juta (95,0\%), SLTP 7.6 juta $(54,9 \%)$, dan SMU/SMK 4,77 juta. Angka buta huruf juga menurun. Tahun 1971 mencapai 31,5 juta, tahun 1980 sebesar 30,1 juta, tahun 1990 sebesar 21,5 juta, dan tahun 1998/1999 semakin mengecil menjadi 11,84 juta orang (Biro Pusat Statistik, 1999).

Demikian halnya di bidang layanan penyelenggaraan pendidikan orang dewasa (continuing education), kegiatan bidang ini cukup menonjol antara lain berupa Kursus, Pendidikan Mata Pencaharian, dan Pelatihan-Pelatihan SDM. Begitu pula peningkatan kualifikasi dan kemampuan guru, pamong, dan tutor, serta pelatihan-pelatihan bagi pengelola pendidikan. Hal lainnya adalah penyempurnaan kurikulum, pencetakan buku ajar, serta pengadaan fasilitas belajar dan pembangunan sarana fisik lainnya.

Di sisi lain indikator keberhasilan itu kenyataannya masih banyak hal yang masih harus perbaiki antara lain gugatan, kritikan, dan isu yang berkaitan dengan mutu pendidikan. Misanya isu kualitas lulusan, rendahnya perolehan NEM, banyaknya anggota masyarakat yang menjadi buta huruf kembali, rendahnya unjuk kerja dalam pekerjaan, dan semakin besarnya angka pengangguran termasuk pengangguran yang berpredikat sarjana (educated unemployment).

Persoalan tersebut diasumsikan memiliki keterkaitan erat dengan berbagai aspek dan komponen yang terdapat dalam sistem pendidikan secara menyeluruh, bahkan erat kaitannya dengan supra sistem sosial negara kita. Namun secara spesifik dan mendasar, dapat diprediksi bahwa permasalahan utama yang segera memerlukan pembenahan adalah pengelolaan program pembelajaran, khususnya metode komunikasi yang digunakan pengajar dalam berinteraksi dengan peserta belajar dalam proses pembelajaran, dengan kata lain terciptanya kondisi belajar pada diri peserta belajar.

Berdasarkan pengamatan dari beberapa kasus pembelajaran, ditemukan indikasi bahwa komunikasi pembelajaran yang telah 
dilakukan pada lembaga-lembaga pendidikan sekolah atau pun pendidikan luar sekolah masih dirasakan kurang kondusif, kurang merangsang peserta didik untuk belajar, sehingga interaksi pengajar dan peserta terjadi dalam suasana monoton. Pada gilirannya kondisi tersebut akan membawa pengaruh pada suasana kegiatan pembelajaran dan mengurangi produktifitas pembelajaran itu sendiri.

Dalam kasus pembelajaran lainnya, terungkap bahwa apabila pengajar memiliki kemampuan mengembangkan komunikasi pembelajaran, maka dengan mudah ia akan mampu menyampaikan bahan belajar, dan mengelola kegiatan pembelajaran. Bahkan selanjutnya akan memberikan dampak positif, bahwa peserta belajar akan lebih mudah menerima, menginterpretasikan, dan mengkajinya lebih lanjut. Sebaliknya, pengajar yang mengalami hambatan dalam mengembangkan komunikasi dengan peserta belajar, menimbulkan dampak suasana kegiatan pembelajaran yang kaku, gersang, dan kurang menarik, sehingga peserta belajar menjadi bosan, dan malas untuk mengikuti pelajaran lebih lanjut (Abdulhak, 2000). Berdasarkan kepada fenomena dan kondisi seperti itu, muncullah permasalahan tentang komunikasi pembelajaran yang bagaimana yang perlu dikembangkan, dan pendekatan apa yang perlu digunakan untuk meningkatkan kualitas, dan efektivitas pembelajaran.

\section{B. PEMBELAJARAN BERKUALITAS}

Pergeseran paradigma mengajar (teaching), yang dimaknai sebagai kegiatan menyampaikan bahan belajar kepada peserta belajar, cenderung bermakna pembelajaran (instruction) yang berarti penciptaan kondisi untuk terjadinya belajar pada diri peserta belajar. Hal ini ternyata membawa dampak terhadap persepsi phenomena interaksi antara pengajar dengan peserta belajar dalam situasi pengajaran tertentu. Perubahan persepsi ini mempunyai implikasi terhadap praktek pengajaran yang dilakukan pengajar dalam mengelola suatu kegiatan pengajaran, dari mulai pengembangan desain, implementasi, evaluasi, dan feedback. 
Dengan tidak melihat dari mana asal kedua istilah tersebut, perubahan paradigma ini berawal dari adanya perbedaan pandangan terhadap peserta belajar. Pada awalnya, peserta belajar diakui sebagai objek atau sasaran, dan merupakan pihak yang pasif dalam komunikasi dengan pengajar. Pengajaran diperuntukkan bagi peserta belajar, sehingga berbagai usaha yang dilakukan pengajar dari mulai mencari, mengumpulkan, memutuskan, dan menyampaikan informasi ditujukan supaya peserta belajar memperoleh informasi.

Paulo Freire (1972), sebagai orang yang mengkritisi pendidikan pada masanya, memandang hal tersebut sebagai praktek "banking system", yang menempatkan peserta belajar pada posisi yang pasif tak berdaya. Peserta belajar hanya mendeposit informasi yang disampaikan pengajar, mendengarkan, mencatat, menghafal, dan menyimpan informasi tersebut dalam pikirannya. Dalam kondisi seperti ini peserta belajar memiliki waktu yang amat sedikit untuk mengungkap, dan memanfaatkan informasi untuk kepentingan umpan balik, sedikit sekali memiliki kesempatan untuk mencoba mengimplementasikan ke dalam kehidupan nyata.

Berbagai kritik terhadap praktek pengajaran tersebut mendorong untuk terjadinya perubahan pandangan terhadap peserta belajar. Dalam pendekatan sistem, peserta belajar ditetapkan sebagai salah satu komponen yang paling menentukan, mulai dari menetapkan komponen-komponen lain, maupun dalam merancang, menyelenggarakan dan menilai efektivitas program pembelajaran. Jone (1987) mengungkapkan bahwa: "The focus is on the student. When planning, teachers first set outcomes and then design instructional activities to match students'prior knowledge, motivation and level of interest. They evaluate available materials and choose presentation strategies to link where student are with where the content is expected to take them. Throughout the process, teachers need to modify their plans countinuosly on the basis of feedback, striving for balance between giving students the guidance they need and the independence they desir". 
Peserta belajar memiliki karakter dan latar belakang yang berbeda. Komunikasi pembelajaran akan terjadi secara efektif apabila keanekaragaman mereka diperhatikan (Oos M. Anwas, 1999). Pembelajaran yang berkualitas dan efektif ditunjukkan oleh ketepatan pemilihan komponen pembelajaran, sehingga secara kolaboratif komponen-komponen tersebut mendukung terjadinya belajar pada diri peserta belajar, memperoleh pengalaman belajar secara maksimal, dan mencapai tujuan belajar yang telah ditetapkan.

Pembelajaran yang berkualitas berkaitan dengan kebermaknaan dukungan komponen--komponen lain terhadap proses belajar yang diikuti peserta belajar sehingga dapat memperoleh hasil belajar yang mendekati standar yang ditetapkan. Sedangkan pembelajaran yang efektif ditunjukkan oleh ketepatan komponen-komponen yang digunakan untuk mencapai tujuan belajar itu sendiri. Killen (1988: 7-10), mengungkapkan bahwa pada hakekatnya pembelajaran yang berkualitas dan efektif ini berkaitan dengan pencapaian hasil belajar yang perlu dikuasai peserta belajar dari sejumlah bahan belajar yang telah ditetapkan, melalui proses pembelajaran yang dirancang oleh pengembang program.

\section{KOMUNIKASI LINIER}

Prinsip komunikasi merupakan prinsip pertama dalam pengajaran maupun pembelajaran (Cole dan Chan, 1994: 13). Komunikasi berkaitan dengan interaksi yang dijalin oleh pengajar dengan peserta belajar dalam memproses pembelajaran. Interaksi menjadi ciri dari keberlangsungan pembelajaran itu sendiri, bahkan dapat dijadikan alat untuk memprediksi perolehan hasil belajar.

Kajian empirik menunjukkan bahwa dengan melalui interaksi yang kuat, hangat, dan bermakna antara pengajar dan peserta belajar, menimbulkan dampak terhadap terjadinya pembelajaran yang berkualitas dan efektif. Berdasarkan data diketahui bahwa pada pembelajaran yang tidak memiliki interaksi yang kuat dan 
mendalam, dengan menggunakan interaksi satu arah, ternyata pemahaman peserta belajar menunjukkan sangat lemah, bahkan memiliki dampak terhadap kurangnya perhatian peserta belajar dalam mengikuti kegiatan belajar (Abdulhak, 2000).

Perkembangan komunikasi dalam lima dasawarsa terakhir, spektrum ilmu komunikasi menunjukkan dinamika yang cukup pesat. Hal ini pun memberi pengaruh kuat pada konteks muatan komunikasi dalam pendidikan, lebih khusus lagi terhadap komunikasi pembelajaran. Pada awalnya konsep teori yang berkembang adalah komunikasi linier yang sering disebut juga dengan komunikasi satu arah atau "one way communication". Seperti yang dikembangkan oleh Claude Shannon dan Warren Weaver (1949). Salah satu ciri komunikasi ini adalah adanya penyandian yang dilakukan pengirim pesan dan interpretasi oleh penerima, serta antisipasi kemungkinan adanya gangguan (noises) dalam proses komunikasi yang berlangsung.

Melalui konsep ini, komunikasi dimaknai sebagai proses penyampaian pesan dari pengirim pesan kepada penerima pesan melalui saluran tertentu untuk tujuan tertentu. Komunikasi linier ini sangat berpengaruh pada konsep mengajar, sehingga peristiwa mengajar itu ditunjukkan dengan proses penyampaian pesan (transmission of messages) yang berupa bahan belajar oleh pengajar (sender) kepada peserta belajar (receivers) melalui pertemuan dan saluran (channel) yang digunakan, sehingga diperoleh produktifitas mengajar berupa hasil belajar yang diharapkan.

Teori komunikasi yang bercirikan linier, memberi pengaruh terhadap komunikasi pembelajaran baik untuk anak-anak maupun orang dewasa, sehingga dampak penggunaan komunikasi ini memiliki kemiripan dengan gejala yang terjadi pada pengajaran. Dominasi pengajar sebagai sumber pesan sangat tampak. Proses pengajaran cenderung satu arah dengan ciri "teacher center" atau guru dianggap sebagai pihak yang paling dominan dan berperan sebagai nara 
sumber yang utama. Metode pembelajaran yang paling lazim dalam model komunikasi linier ini adalah ekspositori, dimana pengajar selalu menggunakan penyampaian informasi dalam mengajarnya.

Model ini bukan sepi dari kritik, kritik terhadap model komunikasi linier ini antara lain dikemukakan oleh Kincaid (1979) yang menyebut ada tujuh bias yang mungkin terjadi, yaitu : (1) Komunikasi linier cenderung bercirikan satu arah secara vertikal, ketimbang komunikasi dua arah atau yang sifatnya siklus, (2) cenderung sangat berketergantungan, terutama dari sumber pesan, (3) fokus obyek komunikasi cenderung sederhana, (4) fokus hanya pada kemasan pesan, dan kurang hirau terhadap waktu yang tepat, (5) Terbatas pada fungsi persuasi, dan belum menyentuh terjalinnya saling pengertian dan konsensus, (6) cenderung terkonsentrasi pada efek psikologis individual, sedangkan efek sosial dan sistem jaringan belum terbina dengan baik, dan (7) cenderung mekanistis dengan kurang hirau pada sistem informasi humanistik.

Pelaksanaan pengajaran yang cenderung menggunakan komunikasi satu arah ini digambarkan dari hasil studi yang dilakukan Ditjen Dikdasmen bahwa proses belajar mengajar dalam kelas yang dikelola guru PKG di SUP masih didominasi oleh guru, dengan bercirikan banyaknya penyampaian informasi, tanpa atau kurang membantu peserta belajar dalam mengembangkan kemampuan belajar mereka, Guru-guru PKG dan sanggar PKG masih sangat pasif, dengan sistem komunikasi yang miskin dalam sikap dan pendekatan mereka terhadap inovasi pendidikan di sekolah dan dalam kelas (1998: 5). Demikian juga terungkap data bahwa alasan peserta Kejar Paket A (untuk anggota masyarakat buta huruf) banyak yang drop outs, hal ini banyak diakibatkan oleh metode yang digunakan tutor cenderung satu arah, dan tidak mendorong peserta belajar untuk mencoba melahirkan aktifitas sesuai dengan potensi dan kemampuannya, sehingga kegiatan belajar menjadi membosankan, dan tidak menarik lagi (Abdulhak, 2000). 
Pemecahan persoalan adanya keterbatasan dan kelemahan penggunaan komunikasi satu arah dalam mengajar, masih tetap berfokus pada penampilan pengajar dalam menyampaikan bahan belajar, dan bukan perbaikan pada proses aktifitas peserta belajar. Perubahan ditujukan untuk memperkuat keterampilan mengajar, mulai dari persoalan daya tarik dalam penyampaian penjelasan (information processing), penguatan (reinforcement), pemberian variasi mengajar (variation), penyusunan rancangan pengajaran, dan penggunaan alat bantu untuk menghilangkan verbalisme. Sehingga dalam setiap mengajar, dirancang penampilan mengajar untuk dapat mewujudkan: (1) adanya kejelasan (clarity); (2) keragaman beraktifitas (variety); (3) berorientasi pada tugas yang ditetapkan (task orientation); (4) berpihak pada kegiatan belajar (engagement in learning); dan (5) merujuk pada rata-rata keberhasilan peserta belajar itu sendiri (student success rates) (Killen: 1998: 7-12).

\section{KOMUNIKASI RELASIONAL}

Dikembangkannya komunikasi yang bercirikan hubungan relational dan interaktif yang disebut dengan "Model Cybernetics " oleh Norbert Wiener yang kemudian dikembangkan lebih lanjut oleh Wilbur Schramm (1973), mempengaruhi konsep interaksi pembelajaran. Salah satu ciri komunikasi relasional ini adalah pentingnya peranan pengalaman (experience) dan faktor hubungan (relationship) antara pengirim dan penerima dalam proses komunikasi. Bidang pengalaman akan menentukan apakah pesan yang dikirimkan diterima oleh si penerima sesuai dengan apa yang dimaksudkan oleh pengirim pesan. Schramm meyakini bila ada perbedaan yang jauh dalam bidang pengalaman, akan mempengaruhi derajat penerimaan pesan yang dikirimkan. Hal lain yang dkemukakan Schramm adalah pentingnya umpan balik sehingga derajat relationship sebagai ciri komunikasi ini akan tampak.

Dalam bidang pendidikan, komunikasi relasional ini sudah melibatkan peran aktif antara pengajar dan peserta belajar. Komunikasi dua arah sudah mulai dibangun dan dikembangkan. 
Walaupun peran guru atau tutor tetap dominan, selain sebagai sumber utama juga berperan sebagai fasilitator kegiatan pembelajaran. Melalui hubungan relasional ini, perbedaan individual peserta belajar (individual differences), sudah memperhatikan secara proposional melalui bimbingan dan perlakuan khusus kendati pembelajaran dilakukan secara klasikal. Metode pembelajaran yang digunakan sudah mengakomodasikan peran peserta belajar dengan segala keragaman dan karakteristiknya yang unik satu sama lain. Oleh sebab itu, mulai perintisan pengembangan Model of Teaching sebagaimana dilakukan oleh Bruce Joyce dan Marsha Weil sejak tahun 1972, yang kemudian dikaji lebih lanjut sampai edisi kelima pada saat ini. la mengklasifikasi model-model mengajar ke dalam empat (4) rumpun, yaitu: The Information Processing Family, The Personal Family, The Social Family, and The Behavioral Systems Family.

Berdasarkan hasil kajian lapangan, ternyata perkembangan konsep pembelajaran dan pengembangan model-model mengajar masih merupakan wacana yang bersifat akademik. Dalam pembelajaran pengajar masih menggunakan cara-cara yang dianggap mudah, dan sudah dikuasainya. Akibatnya belum berpengaruh banyak terhadap perolehan hasil belajar secara merata, dan cenderung tersebar pada kurva normal. Peserta belajar yang aktif hanya didominasi oleh sebagian peserta belajar yang memiliki potensi psikologis yang kuat untuk pengembangan dirinya. Hal ini diperkuat dengan hasil kajian Primary Education Quality Improvement Project (PEQIP), menyebutkan bahwa hanya sekitar $10 \%$ saja sekolah/kelas yang mengindikasikan proses belajar mengajar yang sangat impresif, dengan antara lain bercirikan komunikasi pembelajaran yang menopang terjadinya pembelajaran akti£ Sedangkan $90 \%$ sekolah lainnya, digambarkan sangat lemah. "... ... in other schools, there was little evidence of supportive school and classroom organization and the standard of teaching and learning was consequently lower" (1985: 5). 


\section{E. MODEL KOMUNIKASI KONVERGENSI}

Implementasi model interaktif dalam kegiatan pembelajaran dianggap memiliki beberapa kelemahan. Kelemahan itu antara lain masih ditemukannya variasi perolehan informasi akibat dari kesiapan dan pengalaman yang dimiliki penerima. Hal ini mendorong dikembangkannya pendekatan konvergen sebagai model alternatif yang dapat digunakan dalam proses pembelajaran, dan sebagai upaya untuk mencari model-model terbaik dalam rangka peningkatan kualitas proses dan hasil belajar.

Model konvergen ini pada awalnya dikembangkan Lawrence Kincaid (1979). Makna konvergen adalah "the tendency for two or more individuals to move toward one point, or for one individual to move toward another, and to unite in a common interest or focus". Dengan demikian, salah satu ciri model komunikasi konvergen adalah komunikasi yang berlangsung secara multi arah di antara penerima menuju ke suatu fokus atau minat yang dipahami bersama. Dalam pandangan ini, komunikasi berlangsung secara dinamis dan berkembang ke arah pemahaman kolektif dan berkesinambungan.

Secara historis, komunikasi konvergen ini sebenarnya telah dipopulerkan sejak satu abad yang lalu oleh filsof Charles Sander Peirce. Menurutnya, ada dua prinsip dasar dalam pengembangan komunikasi konvergen. Pertama, informasi dalam kadar tertentu bisa tidak tepat (imprecise) dan bercirikan ketidaktentuan (uncertain). Kedua, komunikasi merupakan proses yang dinamis dan berlaku sepanjang waktu (Rogers, 1981:44). Oleh sebab itu komunikasi konvergen dilakukan secara berkesinambungan melalui suatu jejaring (network) dan didasarkan pada kaidah kolektivitas untuk memperoleh saling kesepahaman "mutual understanding" dalam realitas sosial. Dengan demikian, model komunikasi konvergen akan menyangkut tiga hal pokok, yaitu: 1) Realitas psikologis (psychological reality ), baik individu A maupun B, 2) Realitas fisik (physical reality), 3) Realitas sosial (social reality). Secara diagramatik, model komunikasi konvergen (Rogers : 55) 
adalah sebagai berikut :

\section{Diagram 1: Model Komunikasi Konvergen}

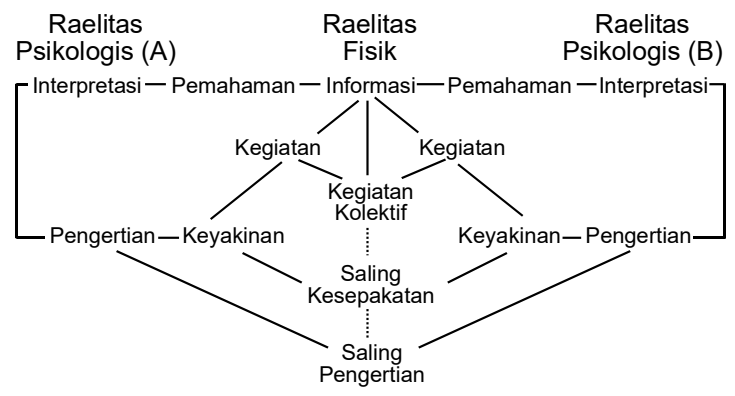

Raelitas Sosial (A \& B)

Dalam komunikasi konvergen, ciri informasi dan saling pengertian merupakan komponen yang sangat dominan. Pemrosesan informasi dilakukan melalui tahapan pemahaman, interpretasi, pengertian dan kegiatan di antara peserta untuk kemudian dicapai saling kesepahaman. Dengan demikian model ini akan merupakan suatu proses yang dinamis manakala mempertimbangkan dua hal : Pertama, pentingnya proses informasi, dan kedua, perlunya saling pengertian antara pihak yang melakukan komunikasi. Dalam kadar seperti ini, komunikasi dipandang sebagai suatu proses yang melibatkan partisipan untuk berbagi informasi agar diperoleh saling pengertian (mutual understanding). Bila dua pihak telah melakukan suatu interaksi komunikasi dengan berbagi informasi yang diperlukan, kemudian terjadi saling pengertian maka derajat saling pengertian di antara keduanya digambarkan oleh irisan di antara dua kelompok lingkaran. Semakin besar daerah irisan, semakin besar lingkup saling pengertian telah dicapai. Dan sebaliknya, semakin kecil daerah irisan, semakin sedikit lingkup saling pengertian telah dicapai.

Dalam pembelajaran, pendekatan komunikasi konvergen ini ditujukan untuk meningkatkan kualitas dan efektivitas pembelajaran, dan sangat memungkinkan untuk diimplementasikan, terutama 
dalam kaitannya dengan menghilangkan kelemahan yang muncul pada model interaktif. Apabila pada model interaktif, pemecahan kesulitan belajar dikembalikan kepada pengajar, maka pada pembelajaran yang memanfaatkan model konvergen ini permasalahan dipecahkan secara bersama-sama di lingkungan peserta belajar- sehingga melahirkan mutual understanding di antara peserta belajar itu sendiri, dan permasalahan diharapkan dapat terpecahkan.

Namun demikian, interaksi pengajar, peserta belajar, dan antar peserta belajar sendiri dapat terwujud secara baik manakala adanya: (1) keterbukaan (openness or transparancy), sehingga tidak ada penghalang dalam melahirkan interaksi; (2) saling memperhatikan (caring), ketika setiap pihak saling memerlukan informasi; (3) ketergantungan satu sama lain (interdependence), yaitu adanya saling berketergantungan antara setiap orang yang terlibat dalam pembelajaran; (4) kemandirian satu sama lain (separateness), setiap orang memiliki kesempatan untuk mengikuti pertumbuhan dan perkembangan keunikan masing-masing; kreativitas, dan individualitasnya; dan (5) saling mempertemukan kebutuhan (mutual needs meeting), yaitu mempertemukan kebutuhan belajar yang sama di antara peserta belajar (Jones: 1998, 75).

\section{F. MANAJEMEN PENDEKATAN KORVERGENSI}

Tahapan pembelajaran yang dirancang dengan pendekatan konvergen ini meliputi: Pertama, pengajar memberikan penjelasan mengenai program belajar, termasuk penjelasan tujuan pengajaran, struktur pengetahuan yang harus dicapai, serta pemberian motivasi untuk mengungkapkan permasalahan dan pengajuan hipotesis, serta langkah--langkah dalam belajar; Kedua, peserta belajar dalam kelompok kecil atau kelas mendiskusikan langkah-langkah sesuai dengan tuntutan program belajar; Ketiga, peserta belajar memformulasikan tugas-tugas pembelajaran; Keempat, pelaksanaan belajar dalam kelompok; Kelima, peserta mengadakan refleksi dengan cara menganalisis kemajuan dan kendala, serta informasi yang diperoleh; Keenam, penyajian perolehan hasil belajar 
untuk dibahas dan dikritisi oleh kelas dan atau oleh pengajar.

Tahapan-tahapan tersebut memiliki beberapa faktor yang terkait dengan model pembelajaran ini, yaitu: pengajar, bahan belajar, peserta belajar, dan sumber belajar. Pengajar memiliki tuntutan untuk merancang skenario pembelajaran, pengaturan kelas, membangun iklim belajar yang kondusif, memonitor jalannya proses pembelajaran, memperhatikan perbedaan peserta belajar, menilai perkembangan partisipasi dan perolehan yang memungkinkan terjadinya interaksi antar peserta belajar. Untuk itu, pengajar perlu memiliki kemampuan dasar (basic competences) yang berguna untuk pelaksanaan pengelolaan pembelajaran dengan pendekatan konvergen.

Hal yang berkaitan dengan bahan belajar dikemas dalam "instructional message design" (Flemming and Levy, 1993: 178) berupa bahan belajar yang sudah melalui proses pengolahan atau perencanaan pengolahan pola tanda dan simbol ke arah tercapainya kondisi belajar yang diharapkan. "Instructional message design is the process of manipulating, or planning the manipulation of a pattern of sign and symbols that may provide the conditions of learning". Bentuk bahan belajar tersebut dapat menggunakan pendekatan induktif atau dedukti£ Bahan belajar induktif ditujukan bagi peserta belajar yang belum memahami konsep dasar bahan yang akan diajarkan. Bahan tersebut berupa kajian dari hal-hal yang mudah ke arah yang sulit. Sedangkan bahan belajar deduktif berupa bahan belajar yang memiliki keterkaitan dengan informasi awal yang sudah diperoleh peserta belajar, sehingga peserta akan mudah mengkaji dan mempelajari bahan belajar tersebut.

Secara lebih rinci Petterson (1993) dalam Plomp (1996:178) menyusun ringkasan prinsip umum disain pesan pembelajaran antara lain sebaiknya memenuhi persyaratan sebagai berikut: a) penyampaian informasi yang relevan sesuai dengan prasyarat yang diperlukan (recall relevant prerequisite information); b) 
mengorganisasikan bahan belajar dan rancangan penyajiannya (organize content and present organizer); c) menyusun bahan belajar dari sederhana ke kompleks (progress from simple to complex); d) penyajian informasi yang beragam (variety information peresented); dan e) menyajikan contoh-contoh (present examples and nonexamples).

Pendekatan ini antara lain menuntut adanya kesiapan peserta belajar untuk berpartisipasi dalam kegiatan belajar secara kooperatif. Karakteristik peserta belajar yang mampu untuk melaksanakan kegiatan belajar ini dilukiskan Johnson and Johnson (1994) dalam Killen (1998: 82-83) sebagai berikut: i) memiliki ketergantungan positif (positive interdependence); ii) memiliki kemampuan berinteraksi secara tatap muka (face to face promotive interaction); iii) memiliki kemampuan tanggung jawab perorangan (individual accountability); iv. memiliki kemampuan penggunaan pendekatan interpersonal yang tepat dalam kelompok (appropriate use of interpersonal skills in group); v. memiliki kemampuan untuk melakukan analisis secara kelompok (group analysis).

Hal lainnya berkaitan dengan sumber belajar yang merupakan media untuk dijadikan rujukan dalam menopang kemudahan belajar. Edgard Dale dalam Plomp dan Ely (1996: 16), menyebutkan terdapat dua jenis sumber belajar (learning resources), yaitu sumber belajar yang dirancang (learning resources by designed) untuk kepentingan pembelajaran yang akan diselenggarakan, seperti buku teks, buku bacaan, media elektronik dan multi media; dan sumber belajar yang dimanfaatkan (learning resources by utilization) dalam pengertian sumber belajar yang tersedia dan mempunyai keterkaitan dengan bahan belajar yang akan dipelajari peserta belajar. Teknis pemanfaatan surnber belajar ini disesuaikan dengan faktor-faktor sebagai berikut: tujuan pengajaran, bahan belajar, karakteristik peserta belajar, serta kemudahan dalam menggunakan bahan belajar. 
Interaksi pembelajaran yang terjadi ditandai dengan hubungan antara pengajar dan peserta belajar, serta interaksi antar peserta belajar. Kedudukan pengajar sebagai pengelola pembelajaran melakukan interaksi dengan peserta belajar dalam kaitannya dengan penataan setting pembelajaran. Tugas lainnya adalah melakukan pengkoordinasian komunikasi antara dirinya dengan peserta belajar dan antar peserta belajar, pemberian motivasi kepada peserta belajar untuk menyampaikan ide/ pengetahuan/pengalaman. Kemudian, pengajar perlu menyampaikan program belajar termasuk bahan belajar di dalamnya, penyampaian masalah yang harus dipecahkan peserta, pemecahan kesulitan yang dihadapi peserta belajar, memberikan umpan balik, serta menilai jalannya komunikasi di antara peserta belajar.

Kedudukan peserta belajar sebagai pihak yang dituntut untuk ikut berpartisipasi dalam pembelajaran memiliki tugas untuk mengungkapkan kebutuhan belajar, mengikuti keseluruhan proses belajar, menyampaikan ide/pengetahuan/pengalaman dalam mengkaji bahan belajar, menyelesaikan tugas yang diberikan pengajar, serta mengimplementasikan konsep ke dalam kasus nyata di lapangan.

Interaksi pembelajaran merupakan suatu proses yang dinamis dengan mempertimbangkan dua hal, yaitu proses komunikasi itu sendiri dan perlunya saling pengertian untuk mencapai hasil belajar yang diharapkan (Rogers, 1986: 55). Lebih jauh Jones (1988: 93) merinci interaksi yang efektif dalam pembelajaran menyangkut halhal sebagai berikut: a) pengajar melahirkan hubungan yang hangat dan bersahabat (be warm and friendly and enjoys relationship), b) pengajar mengungkapkan ide dan program belajar secara jelas (express ideas clearly), c) pengajar memiliki pemahaman yang baik dan bisa menerima peserta belajar secara positif (better understand and accept student and experience more positive feeling), d) pengajar mampu menciptakan situasi yang membuat peserta belajar paham dan merasa diperhatikan (create situation in which student feel understood and cared for). 
Dari karakteristik komunikasi interaktif di atas, pembelajaran yang menggunakan pendekatan konvergen melahirkan lima (5) premis, yaitu: a) pengajar mengharapkan untuk berbagi tanggung jawab dengan peserta belajar dalam memecahkan persoalan pembelajaran; b) pengajar mengakui bahwa peserta belajar memiliki potensi untuk melakukan kegiatan belajar secara mandiri; c) pengajar mengakui bahwa pada dasarnya peserta memiliki tanggung jawab secara individual bila suasana memungkinkan, d) pengajar menerima pengakuan bahwa peserta belajar akan memperoleh perspektif yang banyak dan luas, dan e) pengajar tidak mengharapkan terjadinya konflik antara pengajar dengan peserta belajar. Lebih lanjut O'Learv dan O'Leary (1977) mengungkapkan bahwa untuk memperkuat terjadinya interaksi yang efektif ini terdapat tiga hal, yaitu: 1) Contingency, yaitu proses pembelajaran perlu dilakukan secara cepat dan berlangsung terus , 2) Specification, yaitu pembelajaran seyogyanya dirancang secara khusus dengan memperhatikan kondisi peserta belajar, dan 3) Credibility, yaitu proses pembelajaran perlu dapat dipertanggungjawabkan baik isi maupun proses.

Pada hakekatnya terdapat tiga inti persoalan pokok yang dominan dalam pembelajaran yang menggunakan pendekatan konvergen, yaitu: (1) Bagaimana bahan belajar dikemas dalam bentuk informasi yang tepat; (2) Bagaimana interaksi terjadi secara kooperatif di antara peserta belajar; dan (3) Bagaimana mewujudkan pemahaman bersama (mutual understanding) yang diperoleh setiap peserta belajar (Abdulhak, 2001).

Untuk mewujudkan pembelajaran dalam menjawab persoalan pokok tadi digunakan model pembelajaran yang menggunakan pendekatan konvergen dengan memperhatikan karakteristik di atas sebagaimana digambarkan dalam diagram 2 . 


\section{Diagram 2: Proses pembelajaran dengan pendekatan komunikasi konvergen}

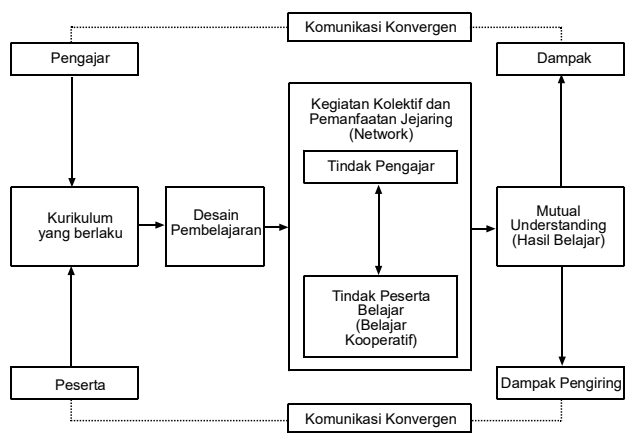

Diagram tersebut mengilustrasikan bahwa belajar merupakan proses internal peserta belajar dan pengajar merupakan faktor eksternal bagi peserta belajar. Proses internal maksudnya adalah perubahan yang terjadi pada diri peserta belajar, melalui jalinan komunikasi interaktif dengan melakukan jejaring (network) di antara peserta belajar itu sendiri. Sedangkan pengajar merupakan faktor eksternal bagi peserta belajar yang berperan sebagai fasilitator untuk mempermudah terjadinya pembelajaran. Output yang dihasilkan adalah berupa pemahaman bersama (mutual understanding) yang diperoleh setiap peserta belajar sesuai dengan tujuan pengajaran yang ditetapkan.

Dalam komunikasi pembelajaran, antar peserta belajar sebaiknya mewujudkan kegiatan belajar secara kooperatif. Terdapat dua hal yang harus disiapkan untuk terwujudnya belajar kooperatif tersebut: Pertama, perlu adanya motivasi peserta belajar (student motivation) untuk terjadinya belajar kooperatif; Kedua, pelaksanaan proses belajar (learning process) yang bercirikan kooperatif (Killen: 1998: 89). 
Secara lebih rinci langkah-langkah belajar kooperatif tersebut adalah sebagai berikut: (1) merumuskan secara jelas apa yang harus dicapai peserta belajar; (2) memilih bentuk kegiatan pembelajaran yang paling tepat; (3) menjelaskan secara detail proses pembelajaran kooperatif yaitu mengenai apa yang harus dilaksanakan, dan apa yang diharapkan; (4) memberikan tugas yang paling tepat dalam pembelajaran; (5) menyiapkan bahan belajar yang memudahkan peserta belajar bisa belajar dengan baik; (6) melaksanakan pengelompokkan peserta belajar; mengembangkan sistem pujian untuk kelompok atau perorangan peserta belajar; (8) memberikan bimbingan yang cukup kepada peserta belajar; (9) menyiapkan instrumen penilaian yang tepat; (10) mengembangkan sistem pengarsipan data kemajuan peserta belajar, balk perorangan maupun kelompok; dan (11) melaksanakan refleksi.

Penggunaan pembelajaran kooperatif ini dilaksanakan melalui sharing process antar peserta belajar, sehingga dapat mewujudkan pemahaman bersama di antara peserta belajar itu sendiri. Pelaksanaan sharing process dalam kegiatan pembelajaran dapat berbentuk kegiatan brainstorming, diskusi kelompok, kerja kelompok, presentasi laporan kelompok, dan feedback dari pengajar.

\section{G. KESIMPULAN DAN REKOMENDASI}

\section{Kesimpulan}

Pokok-pokok kajian pembelajaran yang menggunakan pendekatan konvergen adalah, pertama, pembelajaran dipengaruhi oleh perkembangan ilmu komunikasi. Pada awalnya konsep teori yang berkembang adalah komunikasi linier yang sering disebut juga dengan komunikasi satu arah (one way communication). Hal ini pun memberikan warna pada desain dan model pembelajaran yang cenderung satu arah atau disebut teacher center. Pola ini memiliki banyak kelemahan sehingga menuntut dikembangkannya model pembelajaran lain yang memposisikan peserta belajar sebagai subjek. 
Kedua, Perkembangan komunikasi dua arah memunculkan pendekatan baru dalam mengajar, yaitu pembelajaran yang bercirikan hubungan relasional dan interaktif. Model ini sudah menerapkan peran aktif pengajar dan peserta belajar. Salah satu kelemahan model ini adalah belum berpengaruh banyak terhadap perolehan hasil belajar secara merata, peserta belajar yang aktif hanya didominasi oleh sebagian peserta belajar yang memiliki potensi psikologis yang kuat untuk pengembangan dirinya.

Ketiga, sesuai dengan tuntutan pembelajaran yang berkualitas, dan efektif dikembangkan model pembelajaran yang menggunakan pendekatan komunikasi konvergen. Model pembelajaran ini memiliki ciri pelaksanaan belajar secara berkesinambungan, dan memanfaatkan jejaring (network), serta berpijak pada kaidah kolektivitas untuk memperoleh saling pemahaman (mutual understanding). Konsekwensinya adalah pengajar dituntut selain memiliki kemampuan pemahaman bahan belajar, juga kemampuan untuk menciptakan situasi pembelajaran yang kooperatif di antara peserta belajar.

Keempat, dalam implementasi model pembelajaran yang menggunakan pendekatan konvergen pada dasarnya memadukan karakteristik pendekatan pembelajaran kooperatif, percepatan pembelajaran, belajar yang menyenangkan, dan memperhatikan keunikan individual peserta belajar.

\section{Rekomendasi}

Untuk melaksanakan model pembelajaran tersebut dihadapkan pada berbagai masalah di antaranya bagaimana merancang, mengembangkan, mengimplementasikan, dan menilai model pembelajaran yang menggunakan pendekatan komunikasi konvergen pada setting pendidikan sekolah dan luar sekolah. Ada beberapa implikasi yang secara imperatif berpengaruh terhadap penyelenggaraan kurikulum khususnya pembelajaran pada setting pendidikan sekolah dan luar sekolah, yaitu: 
Pertama, implikasi kepada Lembaga Pendidikan Tenaga Kependidikan (LPTK). Agar lembaga tersebut menyiapkan komponen program akademik yang secara langsung membekali para calon tenaga pengajar untuk memahami, dan mampu mengimplementasikan model--model pembelajaran secara variatif, termasuk model pembelajaran yang menggunakan pendekatan konvergen.

Kedua, implikasi bagi penyelenggara pendidikan sekolah dan luar sekolah, yaitu perlunya memiliki kepedulian akan pengembangan dan pemanfaatan model-model pembelajaran yang berkualitas, dan efektif secara variatif ke arah tercapainya saling kesepahaman di antara peserta belajar sesuai dengan tujuan pengajaran. Kebijaksanaan ini menuntut adanya dorongan balk moril maupun materil dalam bentuk managemen program, perencanaan, dan implementasi yang mengarah pada model pembelajaran secara variatif.

Ketiga, implikasi bagi profesi pengajar, yaitu tuntutan untuk senantiasa adanya peningkatan profesi, termasuk dalam pemahaman perencanaan, dan implementasi model pembelajaran secara variatif khususnya model pembelajaran yang menggunakan pendekatan konvergen. Bentuk process of learning tersebut dapat dilaksanakan pengajar melalui berbagai kajian dalam forum pelatihan, pertemuan pengajar (KKG, dan MGMP), serta mencoba kegiatan pengembangan model pembelajaran melalui classroom action research secara mandiri, atau pun kolaborasi, balk di lembaga pendidikan sekolah maupun luar sekolah.

Keempat, implikasi bagi pihak yang mempunyai kepeduliaan dan kemampuan untuk mengembangkan berbagai model pembelajaran secara inovatif. Hal tersebut dapat dilakukan melalui kajian, dan atau studi lapangan, dengan melibatkan pihak yang terkait yaitu tenaga pengajar, peserta belajar, para 
pengambil keputusan, administrator, dan masyarakat yang mempunyai kepedulian terhadap inovasi pendidikan.

\section{DAFTAR PUSTAKA}

Abdullah, Mardziah Hayati. 2000. Media Literacy. (On Line). Tersedia : http.//www. Ed.go.eric digests. (20 September 2001).

Abdulhak, Ishak. 2001. Model Komunikasi Pembelajaran pada Jenjang

Pendidikan Dasar. Hasil Penelitian. Bandung: Fakultas IImu Pendidikan UPI.

Andira.

2000. Metodologi Pembelajaran Orang Dewasa. Bandung:

1996. Strategi Membangun Motivasi dalam Pembelajaran

Orang Dewasa. Bandung: Agta Manunggal Utama.

Anglin, Gary J. (Ed.). 1991. Instructional Technology. Past, Present,

and Future. Englewood, Colorado: Libraries Unlimited, Inc.

Arends, Richard I. 1998. Learning to Teach. Fourth Edition. Boston: Mc

Graw Hill.

Anwas, Oos M., 1999. Proses Komunikasi dalam Bingkai Reformasi

Pendidikan. Makalah Jurnal Teknodik. Depdiknas. No.6/VI/Teknodik/

April/1999.

Beck, Judy AS dan Wynn, Harriet. 1998. Technology in Teacher

Education: Progress Along the Continuum. (On Line) Tersedia : http./ /www. Ed.go.eric digests. (19 September 2001).

Bigge, Morris L. 1982. Learning Theories for Teachers. Fourth Edition.

New York: Harper \& Row

Boar, Bernard H. 1994. Practical Steps for Aligning Information

Technology with Business Strategies. How to achieve a Competitive

Advantage. New York: John Wiley \& Sons.

Burden, Paul R. Byrd, David M. 1999. Methods for Effective Teaching.

Second Edition.Boston: Allyn and Bacon.

Chauchan, S.S. 1979. Innovations in Teaching-Learning Process. New Delhi: Vikas Publishing House PVT Ltd.

Chow, Vincent WS. (Ed.). 1997. Multimedia Technology and Applications.

Singapore: Springer-Verlag Singapore Pte.Ltd. 
Cole, Peter G. Chan, Lorna K.S. 1994. Teaching Principles and Practice. Second Edition. New York: Prentice Hall.

Cropley, A.J. Dave, R.H. 1978. Lifelong Education and the Training of Teachers. Hamburg: Unesco Institute for Education.

Davis, Robert H. (et al.). 1974. Learning System Design. An Approach to the Improvement of Instruction. New York: McGraw-Hill Book Company. Dick, Walter. Reiser, Robert A. 1989. Planning Effective Instruction. New Jersey: Englewood Cliffs.

Ditjen Dikdasmen. 1998. Meningkatkan Kompetensi Guru dan Mutu Belajar Siswa. Jakarta: Ditjen Dikdasmen Depdikbud.

Dunkin, Michael J. Biddle, Bruce J. 1974. The Study of Teaching. New York: Holt, Rinehart and Winston Inc.

Ellswort, James B. 2000. A Survey of Educational Change Models (On Line). Tersedia : http.//www. Ed.go.eric digests. (25 September 2001). Entwistle, Noel. 1981. Styles of Learning and Teaching. New York: John Wiley \& Sons.

Freire, Paulo. 1972. Paedagogy of the Oppressed. Terjemahan. Jakarta: LP3ES. Gordon, Thomas. 1974. Teacher Effectiveness Training. New York: David MacKay Company.

Gross, Ronald. 1991. Peak Learning. How to Create your Own lifelong Education Program for Personal Enjoyment and Professional Success. New York: Penguin Putnam.

Jalal, Fasli. Supriadi, Dedi. (Ed.). 2001. Reformasi Pendidikan dalam Konteks Otonomi Daerah. Jakarta: Adicita.

Jarvis. Peter. 1992. Paradoxes of Learning. On becoming an Individual in Societv. San Fransisco: Jossey-Bass Publishers.

Jonassen, David H. (Ed.). 1996. Handbook of Research for Educational

Communication and Technology. New York: Macmillan Library Refrence USA.

Joyce, Bruce. Weil, Marsha. 1996. Models of Teaching. Fifth Edition.

Boston: Allyn and Bacon.

Killen, Roy. 1998. Effective Teaching Strategies. Lesson from Research and Practice. Second Edition. Katoomba NSW: Social Science Press. Kindervatter, Suzanne. 1979. Nonformal Education as an 
Empowering Process. Amherst: Center for International Education University of Massachusstes.

Kindsvatter, Richard. Et al. 1996. Dynamics of Effective Teaching. Third Edition. New York: Longman.

Knowles, Malcolm. 1973. The Adult Learner. A Neglected Species. Houston: Gulp Publishing Company,

Levin, James. Nolan, James F. Principles Classroom Management.

Second Edition. New York: Allyn and Bacon.

McLeod, Graham. Smith, Derek. 1996. Managing Information

Technology Projects. Cambridge: An International Thompson

Publishing Company. Miles, Mathew B. 1962. Innovation in

Education. New York : Teachers College Press.

PEQIP Depdiknas. 1998. Basic Education Quality Improvement Project. Jakarta: PEQIP Depdiknas.

Plomp, Tjeerd. Ely, Donald P. (Ed.). 1996. International Encyclopedia of Educational Technology. Second Edition. Cambridge: Pergamon. Rogers, Everett M. 1986. Communication Technology. The New Media in Society. New York: The Free Press.

1983. Diffusion of Innovation. Third Edition London :

The Free Press Collier Macmillan Publishers

Rose, Colin. Nichol, Malcom J. 1997. Accelerated Learning for the 21" Century. New York: Delacorte.

Romiszowski, AJ. 1981. Designing Instructional Systems. Decision making in cource planning and curriculum design. London: Kogan Page. Rylatt, Alastair. 2000. Learning unlimited: Practical Strategies for Transforming Learning in the Workplace of the 21st Century. Warriewood NSW: Business + Publishing.

Seels, Barbara B. Richey, Rita C. 1994. Instructional Technology: The Definition and Domains of the Field. Washington: AECT.

Silberman, Mel. 1996. Active Learning. 101 Strategies to Teach any Subject. Boston: Allyn and Bacon.

Slavin, Robert E. 1995. Cooperative Learning. Theory, Research, and Practice. Boston: Allyn and Bacon.

Somekh, Bridget. Davis, Niki. 1997. Using Information Technology effectively in Teaching and Learning. London: Routledge.

Wittrock, Merlin C. (Ed.). 1986. Handbook of Research on Teaching.

Third Edition. New York: Macmillan Publishing Company. 